\title{
A Design Studio Workshop Proposal for Comparable Evaluation of the First Year Architecture and Interior Design Students
}

\author{
Atlihan Onat Karacali $\odot$ \\ Istanbul Ayvansaray University, Faculty of Fine Arts, Design and Architecture, İstanbul, Turkey
}

Received: October 21st 2020, Revised: December 12th 2020, Accepted: December 14th 2020.

Refer: Karacali, A.O., (2020), A Design Studio Workshop Proposal for Comparable Evaluation of the First Year Architecture and Interior Design Students, Journal of Design Studio, V.2, N.2, pp 183-187,

A.O. Karacali ORCID: 0000-0003-2688-1304,

DOI: $10.46474 /$ jds. 814379 https://doi.org/10.46474/jds.814379

\begin{abstract}
Design studios are the key features of design education. These studios are carried on uniquely and distinctly. Both the progress and grade phases are very special. For architecture and interior design disciplines, the design studio consists of an architectural or interior project design. Design studios are now accepted as the main courses of the semester, and other courses serve as the supportive ones. The traditional architectural presentation techniques used in the design studio were technical drawing and physical modeling. In the last three decades, computer-aided methods joined this list. These three main methods are the base of architectural expression and are taught generally in the first year of education. The following workshop proposal aims to figure out whether the order of these methods is effective in the understanding of first-year students. The workshop is going to choose students from both high and low grades of related supportive courses and divide them into equally distributed groups. A sample structural project is going to be given and each group will follow a different permutation of technical drawing, physical modeling, and computer-aided modeling. All works will be graded at both group and individual levels. Finally, there is going to be comparable data in hand to decide both the more correct permutation and the individual student effort independent from the group.
\end{abstract}

Keywords: Design studio, Design workshop, Technical drawing, Architectural modeling, Computeraided design.

\section{Introduction}

Design studios became the backbone of design education since École des Beaux-Arts (Drexler, 1984). Many famous design schools like Bauhaus and Mackintosh School followed this tradition. Currently, the education of near all design disciplines like architecture, interior design, landscape design, urban design, product design, and even graphic design is based heavily on design studios all over the world. And several studies confirm that the design studio occupies almost half of the design programs (Salama, 1995).
Design studios are carried on in a very special way. They generally take place in an atelier-like bigger classroom environment. Instructors and all other students are involved in the criticism of one's project. Discussions are progressed and individual design solution for each student's very own project is tried to be achieved. Design studios are also special in terms of grading criteria. On the contrary of the theoretic courses which can be graded via classical examination methods, the design studios are mainly evaluated via design juries. Students hang the boards they prepared and present their physical scale models (if any) and a jury of instructors 
and invitees of practicing designers comment on and grade the project.

Successful design curricula are structured on the balance of the studio and non-studio courses (Hacihasanoglu, 2019). Students come across a design studio in all semesters (Ciravoglu, 2014) and it automatically becomes the main course of the semester for its lesson hours and credits. Design studios of consecutive semesters are often linked in terms of prerequisite systems and the design problem becomes more and more complex in the latter semesters (Karacali, Toprak, Acirli \& Manav, 2020). Other courses are considered supportive ones and students are expected to display non-studio teachings directly on the design studio project. Consequently, the design studio is the testing ground for all other knowledge gained.

For architecture and interior design departments, students are expected to design an architectural and interior design project throughout the semester. In these disciplines, there can be even more design studios as a construction system design or a furniture design, in which the student also is expected to design a related project. And the supporting courses of these disciplines can be listed as basic design, technical drawing, architectural sketching, computer-aided design, construction, materials, acoustics, thermal comfort, history of art, furniture, etc.

Not all design studios are progressed in a single way. Though the design studios all have different teaching methods and strategies (named as The Case Problem Model, The Analogical Model, The Participatory Model, The Hidden Curriculum Model, The Pattern Language Model, The Concept Test Model, The Doubled Layered Model, The Energy Conscious Model, and The Interactional Model in Salama's New Trends in Architectural Education: Designing the Design Studio (1995)), the architectural presentation techniques are what we have in common. Presentation is the way the designers use to externalize, communicate and express their ideas. Speaking about the presentation techniques, technical drawing and physical models are the traditional (or manual) ones. However, beginning in the 1990s, with the invention and wider use of personal computers, a brand-new architectural expression method emerged. Many design schools now invest in computational sources to enable their students to provide the necessary skills (Toprak \& Hacihasanoglu, 2019). Computers are now used through augmented reality and virtual reality areas and design education and practice are now evolved into a limitless futuristic concept. With the aid of high-tech wearable devices like VR glasses and some operation tools, it is now possible to walk in the computer model of a project even in the design phase. Returning to basics, we now have three main presentation techniques, and they are taught to architecture and interior design students generally in their first year.

\section{Method}

The following part of this study consists of a design studio workshop proposal dealing with the interactive, collaborative, and experimental learning methods of first-year architecture and interior design students. A bunch of first-year students from supportive courses of technical drawing, physical modeling, and computeraided design are going to be chosen and divided into a non-random but equally distributed mixture of groups. This criterion is stresses to ensure that not all students from similar scores are concentrated in one group. They are then going to be given a simple building. Each group is going to follow a method of a different permutation of drawing, model, and computer. Each work outcome of each student is going to be graded through a well-defined criterion. And the scores are going to be collected and compared. Finally, the most successive permutation in understanding a given structure is going to be figured out. More, the total grades of individual students are going to explain whether the permutational method or individual effort is more effective in achieving the goal.

\section{Case Study}

After the midterms of supportive courses of (technical) drawing, (physical) modeling, and 
computer (aided design) are graded, two students from each higher, intermediate, and lower scores are chosen (six from each course). Additional four substitute students are going to be chosen in case a student could be elected in more than one course. Temporary codes are given to each student in this phase as D1 to D10 ("D" for drawing), same for modeling ("M" codes), and computer ("C" codes) courses. Finally chosen different students are going to be called with codes as D1 to D6. Codes D1 and D2 symbolize higher grades, D3 and D4 are for intermediate grades, and D5 and D6 are for lower grades (Table 1.).

In the second phase, they are going to be divided into six groups of three, based on the different permutations of architectural presentation techniques. Each group consists of one student from different course's different score sectors (Table 2.).

In the third phase, temporary codes are going to be switched with permanent codes as S1 to S18

Table 1. Choice of Students

\begin{tabular}{|c|c|c|c|c|}
\hline & Drawing Course & Modelling Course & Computer Course & \\
\hline \multirow{10}{*}{$\begin{array}{c}\text { Temporary } \\
\text { Student } \\
\text { Codes }\end{array}$} & D1 & M1 & $\mathrm{C} 1$ & \multirow{6}{*}{$\begin{array}{l}\text { Primary } \\
\text { Students }\end{array}$} \\
\hline & $\mathrm{D} 2$ & M2 & $\mathrm{C} 2$ & \\
\hline & D3 & M3 & $\mathrm{C} 3$ & \\
\hline & D4 & M4 & $\mathrm{C} 4$ & \\
\hline & D5 & M5 & C5 & \\
\hline & D6 & M6 & C6 & \\
\hline & (D7) & (M7) & (C7) & \multirow{4}{*}{$\begin{array}{c}\text { Substitute } \\
\text { Students }\end{array}$} \\
\hline & (D8) & (M8) & (C8) & \\
\hline & (D9) & (M9) & (C9) & \\
\hline & (D10) & (M10) & (C10) & \\
\hline
\end{tabular}

Table 2. Workshop Groups with Temporary Student Codes

\begin{tabular}{|c|c|c|c|c|c|c|}
\hline Group & \multicolumn{3}{|c|}{ Student } & \multicolumn{3}{c|}{ Permutational Method } \\
\hline A & D1 & C3 & M5 & Drawing & Model & Computer \\
\hline B & D2 & C4 & M6 & Drawing & Computer & Model \\
\hline C & D3 & M1 & C5 & Model & Drawing & Computer \\
\hline D & D4 & M2 & C6 & Model & Computer & Drawing \\
\hline E & D5 & M3 & C1 & Computer & Drawing & Model \\
\hline F & D6 & M4 & C2 & Computer & Model & Drawing \\
\hline
\end{tabular}

Table 3. Workshop Groups with Permanent Student Codes

\begin{tabular}{|c|c|c|c|c|c|c|}
\hline Group & \multicolumn{3}{|c|}{ Student } & \multicolumn{3}{c|}{ Permutational Method } \\
\hline A & S1 & S2 & S3 & Drawing & Model & Computer \\
\hline B & S4 & S5 & S6 & Drawing & Computer & Model \\
\hline C & S7 & S8 & S9 & Model & Drawing & Computer \\
\hline D & S10 & S11 & S12 & Model & Computer & Drawing \\
\hline E & S13 & S14 & S15 & Computer & Drawing & Model \\
\hline F & S16 & S17 & S18 & Computer & Model & Drawing \\
\hline
\end{tabular}

Journal of Design Studio, v:2 n:2

Karacali, A.O., (2020), A Design Studio Workshop Proposal for Comparable Evaluation of the First Year 
("S" for student) and their performance in previous supportive courses are going to become invisible (Table 3.).

In the fourth phase, these students are going to be given a simple structure. The structure for the first edition of this workshop is chosen as follows (Fig. 1). This is a simple modular fair stand. Both the perspective and the exploded- view are going to be given to students in question (Figure 1.).

In the fifth and the main phase, students are expected to express the structure according to their group's defined permutational model of architectural presentation techniques. For example, three students in Group E are going to study first on the computer model, then on the physical model, and finally on the technical

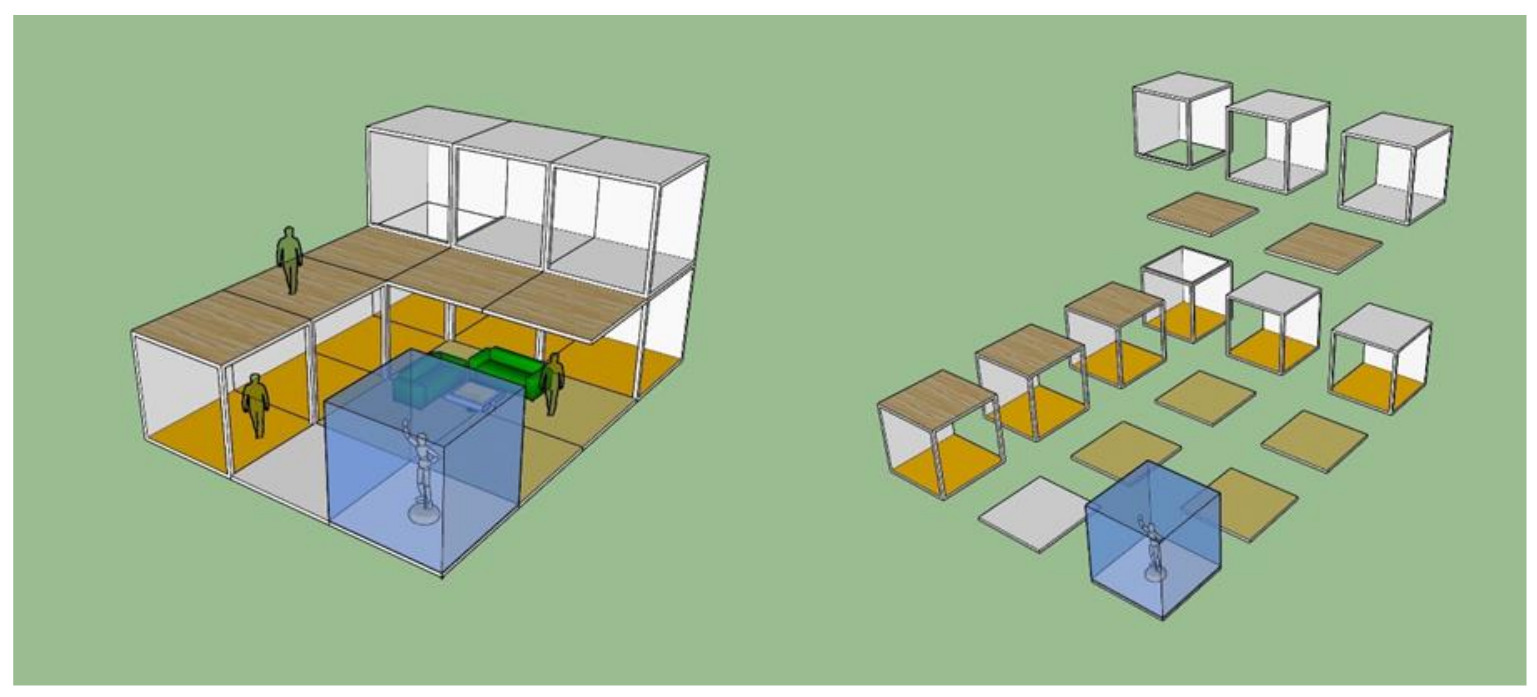

Figure 1. Modular Fair Stand (modelled by the author on SketchUp 2020 program)

Table 4. Workshop Schedule

\begin{tabular}{|c|c|c|c|c|c|c|}
\cline { 2 - 7 } \multicolumn{1}{c|}{} & \multicolumn{2}{c|}{ Day 1 } & \multicolumn{2}{c|}{ Day 2 } & \multicolumn{2}{c|}{ Day 3 } \\
\hline $\begin{array}{c}\text { Environment } \\
\begin{array}{c}\text { Drawing } \\
\text { Atelier }\end{array}\end{array}$ & Morning & Afternoon & Morning & Afternoon & Morning & Afternoon \\
\hline $\begin{array}{c}\text { Modeling } \\
\text { Atelier }\end{array}$ & Group C & Group D & Group A & Group F & Group B & Group E \\
\hline $\begin{array}{c}\text { Computer } \\
\text { Atelier }\end{array}$ & Group E & Group F & Group B & Group D & Group A & Group C \\
\hline
\end{tabular}


drawing. The first edition of the workshop is expected to last three days and to be directed by three instructors in separate ateliers. Each instructor is going to be responsible for one architectural presentation technique in a different atelier classroom. Three ateliers are going to be progressed simultaneously by three instructors (Table 4.).

In the sixth and the final phase, instructors are going to grade each individual work through the well-defined criteria shared with students beforehand. All scores are finally going to be brought together for comparison.

\section{Conclusion}

This workshop has two main outcomes. One is about its availability of comparison in both group level and individual student level. The other outcome is about its renewable identity via its interchangeable features.

After this workshop ends, there are going to be comparable scores in hand. Both score tables for group level and individual student level are going to be prepared. For example, when Group $\mathrm{C}$ is the most successful in terms of grades, the most correct permutational method in terms of first-year students' understanding of the given structure can be listed as the physical model first, then the technical drawing, and finally the computer model. If Groups $\mathrm{E}$ and $\mathrm{F}$ result least successful, the opinion of "beginning with computer model is least useful" can be put forward. Even more, when an individual student's grades are higher separately from his/her group's ranking, yet another solution comes in hand. For example, if Group E is the least successful but Student 14 is on the top ranks in the student grade table, the result of "individual effort is more important than the permutational method" comes out. On the contrary, one may also have lower individual grades within the successful group ranking.

The second result of this workshop proposal can be made after many editions have resulted. As seen, the workshop has many parameters. Other editions must be progressed via changing the department (with another design discipline), or the year (with second, third, or even later year students of architecture and interior design departments), or the given structure (with a more complex or more basic structure), or the students (from the same school or different schools). Or simply another edition of the workshop can be progressed with the same students but in shuffled groups. Many editions are done first, there are going to be enough comparable data in hand. More editions are completed; more correct results are going to be achieved.

\section{References}

Drexler, A. (1984). The Architecture of the Beaux-Arts. London: Secker \& Warburg.

Hacihasanoglu, O., (2019), Architectural Design Studio Culture, Journal of Design Studio, V.1, N.1, pp 5-15.

Ciravoglu, A., (2014), Notes on Architectural Education: An Experimental Approach to Design Studio, Procedia - Social and Behavioral Sciences 152.

Karacali, A.O., Toprak, I., Acırlı, Z., Manav, B., (2020). "İçmimarlık Eğitiminde Konutun Yeri Üzerine Bir Değerlendirme”, 21st Century Housing Discussions Congress, February 1415, Istanbul Ayvansaray University, Faculty of Fine Arts, Design and Architecture.

Salama, A., (1995), New Trends in Architectural Education: Designing the Design Studio. Raleigh, N.C.: Tailored Text \& Unlimited Potential Publishing.

Toprak, I., Hacihasanoglu, O., (2019), Terms and Concepts on Design Studio in the Research Articles of the 2010s, Journal of Design Studio, V.1, N.2, pp 13-22. 